\title{
Assessing Learning Styles of Students at Zayed University
}

\author{
Tofi Rahal \& David Palfreyman
}

Zayed University, UAE

\begin{abstract}
Learning styles based education is becoming influential at higher education institutions around the world. Learning styles are characteristics of how students prefer to learn; they draw their origin from both biological and experiential conditions that make each student unique in the way he/she learns. An important first step in improving learning is to identify or assess students' learning styles, and there are several instruments that can be used for this purpose. This is necessary for teachers and students who wish to improve learning and study strategies. Students who perform poorly in a conventional educational setting may suffer from a mismatch of learning and teaching styles; for example kinesthetic learners may not adapt to learning by listening or by reading. When we teach tactual and/or kinesthetic students by talking, they focus for only a brief amount of time and then wander off into their own thoughts and quickly forget (Burke \& Dunn, 2002). We can improve students' academic performance by providing them with alternative strategies and activities that respond to their learning style needs (Dunn \& Dunn, 1993). In spring 2008, the learning styles of over 700 Zayed University students were assessed using the BE (Building Excellence) survey developed by Rundle \& Dunn. The data collected is being analyzed with a view to making recommendations for teachers, students and parents to improve students' learning. This paper represents the first in a series of publications on this subject; it reviews the survey process, and focuses on the nature and learning preferences of $\mathrm{ZU}$ students in perceptual elements (e.g. visual, auditory) and cognitive elements (e.g. Analytic-sequential (left-brain) vs. Globalsimultaneous (right-brain) preferences).
\end{abstract}

\section{Introduction}

Do not train youths to learning by force and harshness, but direct them to it by what amuses their minds so that you may be better able to discover with accuracy the peculiar bent of the genius of each.

- Plato

Imagine you were an architect assigned to design the construction of a building. What would be the first thing you would do? You would probably examine the nature of the ground to prepare for a sound construction that suits the characteristics and requirements of your building. As an educator you may do the same: examine the nature and characteristics of your students to prepare for sound instruction.

The new emerging global economy and knowledge society call for students who can learn independently and think critically. Simply put, helping students learn more effectively has become vital to improved livelihood and sustained development. Numerous authors acknowledge the failure of traditional teacher-based approaches in delivering independent lifelong learners, since they do not meet students' diverse learning abilities and styles (Freire, 1973; Terenzini \& Pascarella, 1994; Palmer, 1998; Komives, 2003). In the last three decades, educational institutions all around the world are increasingly considering learning and thinking styles as a basis to improve students' learning. 
This paper uses data from a research project funded by Zayed University (ZU)'s Research Incentive Fund on the subject of learning styles in the Gulf region. The project supports the use of learning style models as a theoretical and research framework to improve the process of educational reform and student learning in higher education; it aims to identify the learning styles of students and to use this knowledge to teach students accordingly. The Dunn and Dunn learning styles model was specifically used to measure and describe statistically the nature and learning preferences of $\mathrm{ZU}$ students on perceptual elements such as visual, auditory, reading/writing, and kinesthetic preferences, as well as cognitive elements such as analytic sequential (left-brain) vs. global simultaneous (right-brain) preferences.

\section{Review of Learning Styles Models}

Learning may mean different things to different people. At the heart of this debate are key questions such as:

- How do people learn?

- Do all people learn the same way?

- Is the ability to learn a function of genetic predisposition?

- Can educational institutions change the ways students learn?

- What are the limitations of our learning?

- What kind of learning do current educational systems seem to be promoting the most?

- What types of students seem to be benefiting/suffering the most from current practices?

- Can students improve their own ways of learning?

For a long time, educators and psychologists have attempted to address these and other related questions. They agree on some points, and disagree on many others: hence the emergence of many learning style models in the literature (and on the market). Most of these models support the view that students learn differently and are better served when curriculum designs and instructional methods attend to their differences. Howard Gardner (1983) outlined eight types of 'intelligence' that give students different abilities to learn. Renzulli et al. (2000) used principles of constructivist differentiated learning to devise varying instructional strategies and techniques to meet the needs of all students. Jung (1921) and later Myers-Briggs (e.g. Myers-Briggs \& McCaulley, 1985) proposed various types of personality which differentiate how students learn and work according to the way they perceive and react to the world.

In the past three decades, numerous research studies have emerged in support of learning style models. Dunn (1989), Entwistle \& Hanley (1979), Gregorc \& Butler (1984), Keefe \& Ferrell (1990), Kolb (1984), Felder \& Silverman (1988) and others have emphasized the need to assess and identify students' learning styles as a basis for improving learning. Learning styles theories and inventories have become important tools of teaching and learning centers in much of the western world. However, Dunn (1997) has noted that the process of infusing conventional instructional approaches with learning style strategies has been slow. This slow infusion may be caused partly by mismatch between instructional styles of teachers and learning styles of students: teachers tend to use instructional styles congruent with the way they themselves learn rather than how their students learn (Arden-Close, 1999): Whitefield (1995) suggests the majority of schoolteachers take an analytic approach, while a minority of high school students are analytic learners. Reiff (1992), found that most of the students who were not doing well in school were kinesthetic or tactual learners - styles which Bahoora (1996) found were

Rahal, T. \& Palfreyman, D. (2009). Assessing learning styles of students at Zayed University. Learning and teaching in higher education: Gulf perspectives 6(2). http://www.zu.ac.ae/Ithe/Ithe06_02_01_rahal.htm 
common among (especially male) Arab middle school students in the USA. Although some teachers do experiment with various instructional approaches such as case studies, cooperative learning, independent studies, role playing, and simulations to improve their students' motivation and academic achievement, these strategies may be no more effective than lectures or readings, particularly with atrisk students (Boyle \& Dunn, 1998; Jones \& Watson, 1990), if they do not pay close attention to how students learn.

The Dunn \& Dunn Learning Styles Model has a great deal of history and research behind it: since its inception in 1975 it has been supported by hundreds of research studies all around the world. The model traces its roots to two main distinct learning theories: Cognitive Style Theory and Brain Lateralization Theory. Cognitive Style Theory is based on the idea that individuals process information differently on the basis of either learned or inherent traits. Brain Lateralization Theory is based on the idea that the two hemispheres of the brain have different functions: the left brain covers verbalsequential abilities (Analytic), while the right brain deals with emotions-spatial holistic processing (Global).

Dunn (1989: 50) defines learning style as:

the way in which individuals begin to concentrate on, process, internalize, and retain new and difficult information... a biologically and developmentally imposed set of personal characteristics [which] makes the same teaching method effective for some students and ineffective for others.

The model incorporates certain basic principles shared with other learning style models:

- Everyone has strengths, but different people have different strengths.

- Most individuals can learn.

- Instructional environments, resources, and approaches should respond to diversified strengths.

- Individual instructional preferences exist and can be measured reliably.

- Given responsive environments, students attain statistically higher achievement and aptitude test scores in matched, rather than mismatched treatments.

- Most teachers can learn to use learning styles as a cornerstone of their instruction.

- Many students can learn to capitalize on their learning style strengths.

The Dunn and Dunn Learning Style Model incorporates elements of other learning style models, drawing these together into five different learning style areas. A total of 21 elements may be used by students in varying degrees as they try to learn new and difficult information. According to Dunn and Honigsfeld (2006), an individual student is likely to have significant preferences for 6-14 of these elements: these compose that individual's learning style. To profit from their learning styles, students need to be well aware of their various inclinations and strengths. Below is a list of the areas and elements of the original Dunn and Dunn learning styles model, summarized in pictorial form in Figure 1.

- Environmental: preferences regarding sound, light, temperature, and design.

- Emotional: characteristics of motivation, persistence, responsibility, and structure.

- Sociological: preferences for involvement of self only, pairs, peers, teams or a variety of these. 
- Physiological: preferences for perceptual modality, intake of food and drink, time of day and mobility while learning.

- Psychological approach: global/analytic, impulsive/reflective.

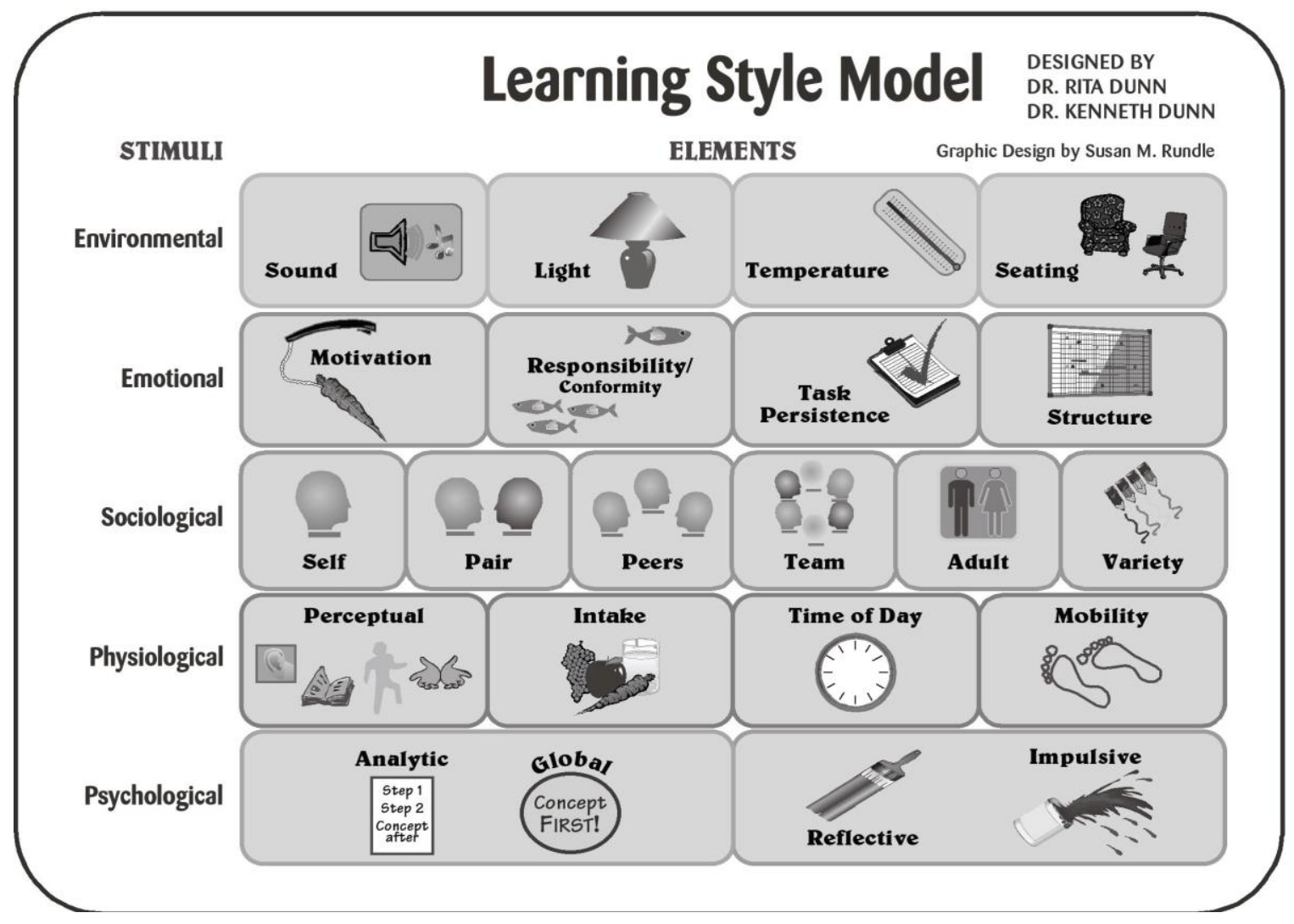

Figure 1: Dunn and Dunn learning style model.

The perceptual element was later emphasized by Rundle \& Dunn (1996), who made a separate strand for perception containing the following elements: Auditory (by listening), Visual (by looking, divided into Visual-Picture (images) and Visual-Word (reading)), Tactual (with the hands), Kinesthetic (by moving the whole body) and Verbal (by talking).

Like most prominent learning styles models (e.g. those of Kolb, of Felder and of Myers-Briggs), the Dunn and Dunn model comes with well established inventories to identify and assess students learning styles. The assessment instruments that come with the model vary depending on the age of students. For a list of various assessment instruments and the corresponding age and grade levels see Table 1.

Table 1: Dunn \& Dunn assessment instruments.

\begin{tabular}{|l|l|l|}
\hline OPALS & Pre-K/Primary School & Ages 4-5, Grades Pre-K-2 \\
\hline ELSA & Elementary School & Ages 6-8, Grades 3-4 \\
\hline LSCY & Middle School & Ages 9-13, Grades 5-8 \\
\hline LIVES & High School & Ages 14-17, Grades 9-12 \\
\hline BE $^{\circledR}$ & Adult & Ages 17 and Older \\
\hline
\end{tabular}

Rahal, T. \& Palfreyman, D. (2009). Assessing learning styles of students at Zayed University. Learning and teaching in higher education: Gulf perspectives 6(2). http://www.zu.ac.ae/Ithe/Ithe06_02_01_rahal.htm 
Table 2 below gives a brief explanation of each element in the Dunn and Dunn model.

Table 2: Elements of the Dunn \& Dunn model.

\begin{tabular}{|c|c|c|}
\hline Category & Elements & Description \\
\hline \multirow{6}{*}{ 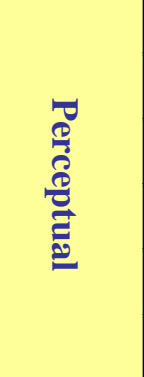 } & Auditory & Whether you learn better by listening and hearing. \\
\hline & Visual Picture & $\begin{array}{l}\text { Whether you learn better by using your mind's eye or seeing } \\
\text { illustrations and graphs. }\end{array}$ \\
\hline & Visual Word & $\begin{array}{l}\text { Whether you prefer seeing words instead of pictures; i.e. written } \\
\text { directions instead of map }\end{array}$ \\
\hline & Tactual & $\begin{array}{l}\text { Whether you prefer to learn by using physical sensory input } \\
\text { (hands on). }\end{array}$ \\
\hline & Kinesthetic & Whether you prefer to learn by moving and acting (on foot). \\
\hline & Verbal & $\begin{array}{l}\text { Whether you prefer to express yourself to other people or aloud to } \\
\text { yourself. }\end{array}$ \\
\hline \multirow{2}{*}{ 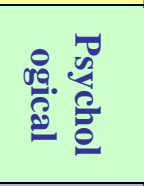 } & Analytic/Global & $\begin{array}{l}\text { Whether you prefer to build up your knowledge piecemeal from } \\
\text { facts and figures (Analytic), or you prefer to get the Big Picture } \\
\text { first and slot in the detail afterwards (Global). }\end{array}$ \\
\hline & Reflective/Impulsive & $\begin{array}{l}\text { Whether you prefer to think about and weigh all your options } \\
\text { before making a final decision (Reflective), or you hastily take } \\
\text { your decision (Impulsive). }\end{array}$ \\
\hline \multirow{4}{*}{ 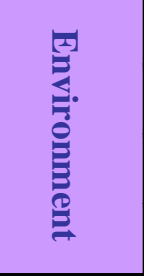 } & Sound & Whether you prefer to have sound while working or silence. \\
\hline & Light & The best amount of light you prefer when working. \\
\hline & Temperature & Whether you prefer to work in a warm or cool temperature. \\
\hline & Seating & $\begin{array}{l}\text { Whether you prefer to study while sitting at a desk (Formal) or on } \\
\text { the floor with cushions, or on a sofa or bed (Informal). }\end{array}$ \\
\hline \multirow{6}{*}{ 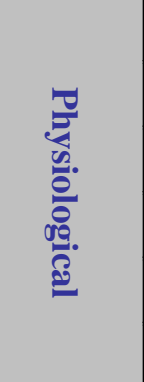 } & Early Morning & Whether you are more productive early morning. \\
\hline & Late Morning/Early Afternoon & Whether you are more productive late morning/early afternoon. \\
\hline & Late Afternoon & Whether you are more productive late afternoon. \\
\hline & Evening & Whether you are more productive in the evening. \\
\hline & Intake & Whether you prefer to take snacks while working or studying. \\
\hline & Mobility & Whether you prefer to move while studying. \\
\hline \multirow{4}{*}{ 절 } & Motivation & How much inner drive you have. \\
\hline & Task Persistence & $\begin{array}{l}\text { Whether you prefer to stick and complete a task before you go to } \\
\text { another. }\end{array}$ \\
\hline & Conformity & $\begin{array}{l}\text { How much influence other people opinions has on you or whether } \\
\text { you prefer to take the risk and challenge. }\end{array}$ \\
\hline & Structure & $\begin{array}{l}\text { Whether or not you prefer to have precise information on how to } \\
\text { perform a task. }\end{array}$ \\
\hline \multirow{6}{*}{ 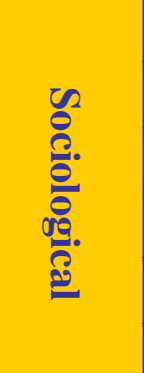 } & Alone & Whether you prefer to work alone. \\
\hline & Pair & Whether you prefer to work with a friend. \\
\hline & Small Group & Whether you prefer to work as a part of a small group. \\
\hline & Large Group & Whether you prefer to work as a part of a Large group. \\
\hline & Authority & Whether you prefer to work with an adult or expert present. \\
\hline & Variety & Whether you prefer to follow the same routine in doing a task. \\
\hline
\end{tabular}

Table 2: Elements of the Dunn \& Dunn model. 


\section{Why the Dunn and Dunn Model?}

The Dunn and Dunn model offers an effective theoretical framework to inform the process of educational reform and research in higher education. It offers a Learning Styles Inventory for assessing college students, the reliability and validity of which have been tested and established by research studies (e.g. LaMothe et al., 1991). The Building Excellence survey based on this model provides many advantages:

- It can be self-administered and self-scored by both students.

- It can generate automated Learning Style Productivity Profiles (LSPP) for individual students as well as groups, such as schools, emirates, gender, academic stream and so on.

- Each profile is presented in a graphical and textual forms, which is easy to understand, follow, and interpret by students, teachers and parents.

- It is easy to translate into Arabic (this is already been done by the Author).

- It is comprehensive. It deals with many learning modalities; e.g. perceptual, environmental, physiological, sociological, emotional, and psychological.

- It falls into the instructional category which applies directly to schools and educational systems.

- It has the support and resources of well-equipped team of experts.

- It is suited to diverse cultures, languages, and conditions.

- It can be easily modified to include demographic, social, or cultural variables of interest to educators and/or social scientists.

- The validity and reliability of the assessment instrument are well established by research.

\section{Limitations of the Dunn and Dunn Model}

The main thesis of the Dunn and Dunn model is this: using instructional strategies that are responsive to students' learning styles will improve their academic achievement and attitude toward learning. Various authors (e.g. Kavale \& LeFever, 2007) claim that the Dunn and Dunn Model requires further testing in independent studies, since most of the research performed on the model has been done by the Dunns, their associates or supporters.

Learning styles are generally stable, but some learning styles are developmental and many people's styles change as they grow older. Motivation level can also have a varying effect on the learning style base of an individual. This requires continuous assessment of students and alteration of instructional methods.

Life is not always designed to perfectly suit us or suit our learning styles. We are often faced with situations that require skills and abilities that fall outside our learning styles or "comfort zone". As we try to meet students' learning preferences we should also pay attentions to using strategies that develop their less favored styles. In an ongoing research on learning styles of students at Zayed University, Rahal (2009) proposed an enhanced model of learning styles. The model consists of learning style highs (LS Highs), which correspond to students strengths/preferences, and learning style lows (LS 
Lows) representing students less favored styles. Instructional strategies which are responsive to LS Highs improve students' learning. Improved learning will then yield a higher level of student motivation, and motivated students will become more willing to address and improve their less favored learning styles (LS Lows), which in turn improves long-term learning further. This way we are not only improving students' learning but also expanding their learning style base and their learning comfort zone. Thus, students become better equipped to be independent long-life learners. Figure 2 shows the basic principle of the enhanced learning style model (ELSM) developed and proposed by Rahal (2009).

The two upper arrows indicate how learning emphasizing learning style highs or strengths lead to student motivation; the two lower arrows indicate how motivation can help students to cope with learning style lows and therefore improve learning even further.

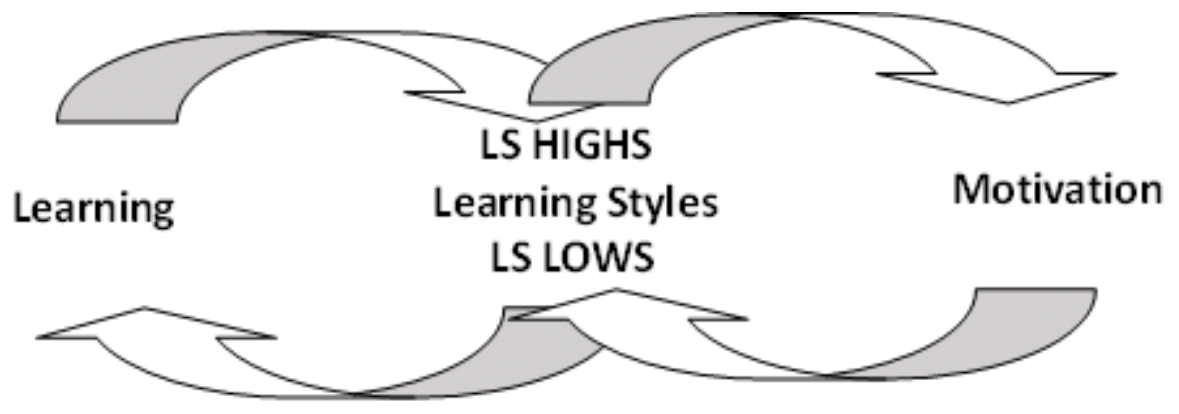

Figure 2: Model for addressing students learning lows (Rahal, 2009).

\section{Focus of the present study}

As outlined above, the Dunn and Dunn model and surveys consider a great range of different kinds of learning preferences. The Zayed University Learning Styles Project involves assessment of the range of these learning styles; however, within the scope of this paper we will focus on two areas of the model: perceptual preferences such as visual and auditory, and psychological styles: Analytic/Global and Reflective/Impulsive.

\section{Learning Context}

Zayed University (ZU) is a government university in the UAE, established in 1998 to provide higher education for UAE citizens (who form approximately 20\% of the country's population). Since 1998 two campuses (one in Dubai and one in Abu Dhabi) have provided undergraduate courses for female students, with a current student population across the two campuses of approximately 3,500.

The education system of the UAE has been developing since the oil boom of the 1970's provided funding for this: as a result, the current students' educational career is very different from that of their parents' generation. For example, many of our students' mothers received only primary level education or less, and their fathers may not have completed their secondary education. Older brothers may have received university education in other countries, while students' older sisters often received university education within the UAE (Palfreyman, 2006). If learning style is linked to level of education and early input within the family, then the disparity between the generations may be a significant factor in ZU students' learning styles. 
Other features of students' background seem potentially relevant to shaping their previous learning experiences and their learning preferences. Some students live in urban areas such as the cities of Abu Dhabi or Dubai; others come from more rural areas outside these cities, or from smaller emirates such as Sharjah or Ajman. Many students attended government schools where classes are larger and the medium of instruction is usually Arabic, while some come from (often better resourced) private schools where English tends to be predominant.

ZU's curriculum is conducted mainly in English, and consists of three main stages: Academic Bridge Program (ABP - sometimes referred to as "Readiness"), General Education (GE - also referred to in ZU as "Colloquy on Integrated Learning") and Major programs. Most students entering the university are required to join the ABP: a foundation program of from ten to eighty weeks which focuses mainly on developing students' English skills to enable them to enter an academic environment. On successful completion of the ABP (or of an equivalence exam), students enter their degree program, which lasts approximately four years. This begins with the General Education (GE) program, which provides a broad base of academic content in subjects such as English Composition, Global Studies, Quantitative Skills and Arabic. GE courses are denoted as level 1 or 2, and are required of all students. Once students have successfully completed level $1 \mathrm{GE}$ courses, they can start to take courses towards their Major of study, often concurrently with level 2 GE courses. These level 3 and 4 major courses are organized within five colleges: Business, Communication \& Media, Education, Information Technology and Arts \& Sciences.

\section{Methods}

For this study we used the Building Excellence (BE) survey (Rundle \& Dunn, 1996-2007). The survey consists of 124 short items, each focusing on a particular element of the Dunn \& Dunn model. For each item in the $\mathrm{BE}$, learners are asked to select one of five agreement responses, e.g:

I like learning with friends rather than alone.

Strongly Disagree/ Disagree/ Neither Agree nor Disagree/ Agree/ Strongly Agree

The online administration of BE suited the target population of ZU students, since all students are required to have a laptop for use in their studies and are accustomed to using online services.

In late February/early March 2008, the BE survey was piloted with 21 students in the highest level of ZU's Academic Bridge (Readiness) Program. This level was chosen because the students' English language proficiency would be approaching that of the students in the General Education/ Majors programs to be surveyed in the main study. The researchers administered the survey in two classes in order to observe how the students coped with it from a logistical point of view, and to gain their feedback on the survey as a whole. The researchers preceded the survey with a presentation which introduced the concept of learning styles and previewed the kind of items that occur in the survey.

Excluding time spent on introducing the survey and dealing with any technical problems with network connections, students were able to complete the survey within 30-40 minutes of class time. The information gained from the piloting process enabled us to make changes in preparation for the main administration of the survey:

- The introductory presentation took up too much time, making the whole process longer than a 50-minute class. In the main study we therefore condensed the introductory presentation to the essentials (see Appendix 1).

- We noticed that students were unfamiliar with certain vocabulary in the survey items (e.g. productive; intuitively); but for the most part they were able and willing to use strategies to find 
out the meaning (asking a teacher or looking up the meaning of word on their computer). For the main study the introductory presentation highlighted these strategies, and administering teachers were provided with Arabic translations of potentially difficult words in case these were needed.

- We noticed that some students had difficulty responding to negative statements (e.g. Early morning is not my most productive time to work on difficult tasks). In the main study we included an example of this in the introductory presentation, and clarified what it means to agree or disagree with such a statement.

In negotiation with Learningstyles.net we added demographic questions to the BE survey for our students. This enabled us to gather data on each student's

- University ID number

- Area of residence

- Type of high school (government or private)

- Main language used at high school

- Length of time studied in the Academic Bridge ("Readiness") Program.

- Current semester (first/second/third/...)

- Registered major (if any)

- Present GPA

- Mother's level of education

The survey was administered in class time by teachers (wherever possible with a researcher in attendance to assist). In each case one of the researchers or the class teacher spent 10 minutes going through the introductory presentation (see Appendix 1), explaining that participation was not compulsory, emphasizing that we were interested in students' own preferences rather than those of friends or parents, getting the students started on the survey and dealing with any logistical difficulties. Then the students spent approximately 40 minutes completing the survey, during which time the teacher (and researcher if available) were available to answer queries and to discourage discussion of responses before the survey was completed.

In April-May 2008, 844 students in ZU's GE and Major programs registered and began the survey, and of these 726 completed the survey: 512 from ZU's Dubai campus and 214 from the Abu Dhabi campus. This ratio between the two campus samples reflects the greater size of the student population in Dubai.

Since the survey was administered by teachers in class time (to facilitate the response rate), the selection of students surveyed was done by class, making an effort to survey a spread of different departments and levels in the university. Table 3 shows the number of students from different types of classes who completed the survey (note that this does not necessarily reflect the students' major field of study, which was ascertained by an item in the survey). Sampling was contingent on teachers' willingness to give the researchers 50 minutes of their class time. As a result, while all colleges and levels of study were included in the sample, the number of students in each cell in Table 3 is representative only in a very general way of the number of students studying that type of course in the university. 
Table 3: Students surveyed by class ("?" signifies students who did not indicate their classes in the survey).

\begin{tabular}{|l|c|c|c|c|c|c|c|}
\hline Level & GE & Business & Communication \& Media & Education & Information Technology & ? & Total \\
\hline $\mathbf{1}$ & 322 & 0 & 29 & 14 & 0 & - & $\mathbf{3 6 5}$ \\
\hline $\mathbf{2}$ & 23 & 91 & 20 & 0 & 0 & - & $\mathbf{1 3 4}$ \\
\hline $\mathbf{3}$ & 0 & 0 & 19 & 15 & 9 & - & $\mathbf{4 3}$ \\
\hline $\mathbf{4}$ & 0 & 61 & 6 & 0 & 0 & - & $\mathbf{6 7}$ \\
\hline $\boldsymbol{?}$ & - & - & - & - & - & $\mathbf{1 1 7}$ & $\mathbf{1 1 7}$ \\
\hline Total & $\mathbf{3 4 5}$ & $\mathbf{1 5 2}$ & $\mathbf{7 4}$ & $\mathbf{2 9}$ & $\mathbf{9}$ & $\mathbf{1 1 7}$ & $\mathbf{7 2 6}$ \\
\hline
\end{tabular}

The $B E$ web survey provides three kinds of output:

- an individual report for each student, including a summary learning style profile (with a summary band (e.g. strong preference, moderate preference) for each learning style element, as well as more detailed comments and suggested learning strategies with respect to the individual's learning style profile. The researchers and class teachers encouraged students to review their own report after completing the survey.

- an aggregate report for each group of students, giving the percentage of students within each band for each learning style element. Where possible, the researchers forwarded this to the class teacher for his/her reference.

- a spreadsheet of all individuals' scores for each element of the Dunn and Dunn model, as well as their responses to the demographic questions. The researchers used this for the following statistical analysis using SPSS.

\section{Findings}

As mentioned earlier this paper will focus on data for two areas of the Dunn and Dunn model, including six perceptual preferences (e.g. visual, auditory) and two psychological styles: analytic/global and reflective/impulsive. We will summarize overall trends in these areas, and consider patterns in variation among sub-groups of students identified by the demographic questions. Reference will be made throughout to statistical tables in Appendix 2 and Appendix 3.

\section{Perceptual preferences}

The $B E$ tests for six perceptual learning styles:

Auditory (e.g. When learning, I remember best when I hear someone talk about the topic).

Verbal (e.g. When learning, I remember best when I talk to myself).

Kinesthetic (e.g. When learning, I remember best when I am physically involved in activities).

Tactual (e.g. I remember best when I am doing something active with my hands while I am learning).

Visual-picture (e.g. When learning, I remember best when I picture in my mind what I hear).

Visual-word (Reading) (e.g. When learning, I remember best when I see words rather than charts and graphs). 


\section{Overall profile}

Figure 3 below shows students' 'favourite' perceptual learning styles, considering only each student's most positive responses; the chart shows how many students favoured each style. It is clear from the chart that there are a great variety of preferences among the students, with all styles favoured by at least $8 \%$ of the students. Verbal appears to be the most favoured style: $27.6 \%$ of highest preferences were for this style (note that this study includes only female informants; this finding may be related to a tendency for females to learn verbally, cf. Northwestern University, 2008). The second most favoured is Visual-Picture, followed by Tactual. The least favoured style, by this measure, is Kinesthetic.

Figure 3: Percentage of students for each perceptual preference.

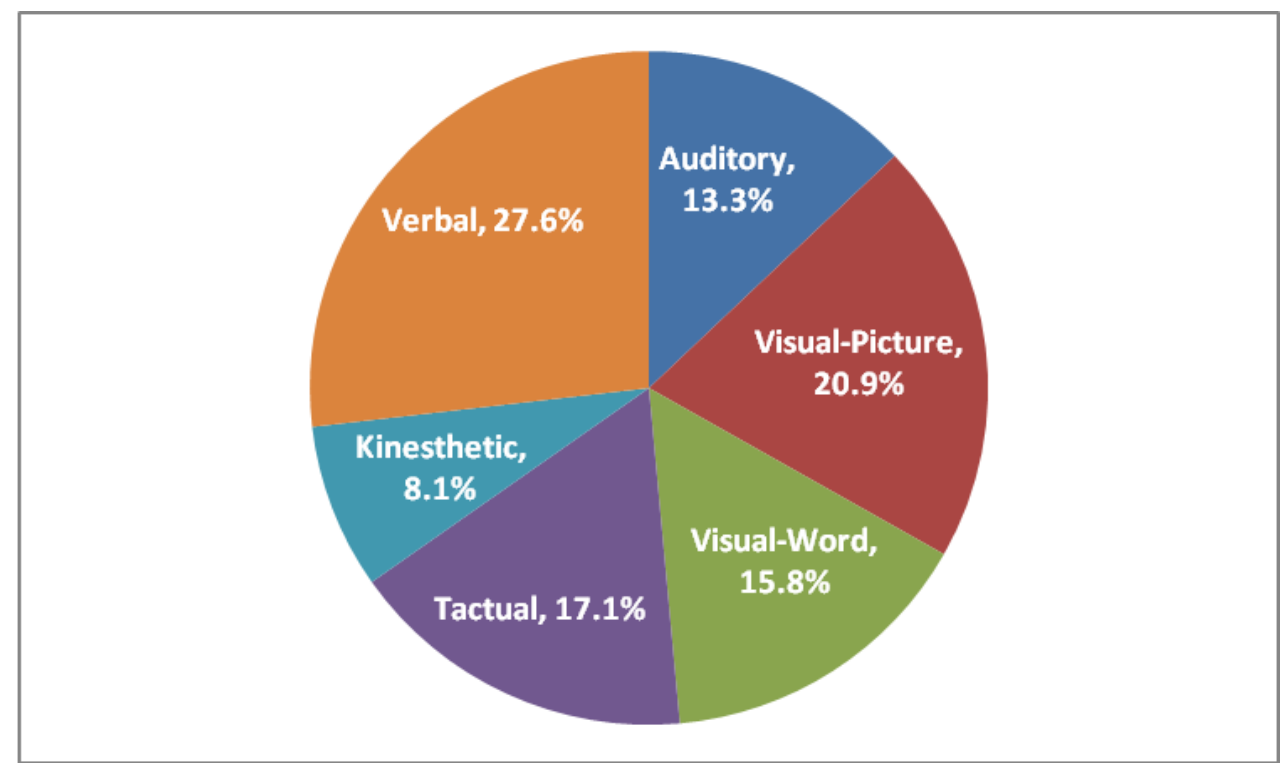

Table 4 shows mean scores among all the students for the different perceptual styles, where -100 indicates a response of "Strongly Disagree" to all the survey items related to that style, +100 indicates "Strongly Agree" with all those items, and 0 indicates a mixed/neutral response. Consistent with Figure 3, Verbal is the highest-rated perceptual style, followed by Visual-Picture; Auditory and Kinesthetic styles are the lowest rated. Note however that there is considerable variation in students' responses: for Verbal, approximately $68 \%$ of students were spread across a range from 25.9 (slightly positive) to 84.9 (strong preference). For the less favoured styles the variation is greater, e.g. for Kinesthetic a similar number of the students are spread from -25.9 (slightly negative) to 57.3 (moderately positive).

Table 4: Scores for each perceptual element of learning style.

\begin{tabular}{|l|l|l|}
\hline & Mean & Standard Deviation \\
\hline Verbal & +55.4 & 29.5 \\
\hline Visual-picture & +47.4 & 34.6 \\
\hline Visual-word & +41.1 & 25.1 \\
\hline Tactual & +40.0 & 32.9 \\
\hline Auditory & +32.7 & 39.7 \\
\hline Kinesthetic & +15.7 & 41.6 \\
\hline
\end{tabular}




\section{Perceptual style patterns within the student sample}

In this section we consider statistically significant differences between different categories of students, based on each student's most favoured perceptual learning style and their responses to the demographic questions (see Methods). Appendix 2 shows the total number of students responding in each category for each of the demographic questions; note that as mentioned below, very small subgroups within our sample (e.g. students from the northern emirates and in certain majors) were omitted where relevant to improve statistical reliability.

Some perceptual styles (especially the less favourite ones such as Kinesthetic) showed no significant correlation with the demographic items, but we will focus on the patterns that did emerge. One of the most significant demographic variables in this regard is the type of high school from which the student graduated (private or government); this will be discussed further below.

\section{Verbal}

Verbal (learning by talking to oneself or others) was the most often favoured style among the students overall (see Figure 3 above); but it is particularly popular among students coming from private schools. A slight majority of these students (54.5\%) gave the Verbal style their most positive response; whereas among government school graduates a minority (albeit large: 39.8\%) gave such a response (Table 5 in Appendix 3), perhaps reflecting greater opportunity/incentive in private schools for students to express their learning verbally.

Note that because private and government schools differ in various ways, other variables which we tested for also correlate with this learning style (and also with other learning style preferences). For example, private schools tend to use English and government schools Arabic; students from private schools are therefore more likely to enter the university without studying in the Academic Bridge Program; they also tend to have higher GPA's. As a result, a preference for Verbal learning is common among students coming from English-medium schools, those having a higher GPA and those having studied for a short time (or not at all) in the Academic Bridge Program. However, it seems likely that these all stem from the type of school, rather than because of these other variables: for example, students from Arabic-medium private schools are no less likely to prefer this style than students from English-medium private schools (Table 6 in Appendix 3).

\section{Visual-Picture}

Visual-Picture is the second most favoured style among the students overall. Again there is some relationship with the type of high school from which students come, but this time in the opposite direction: students from government schools are more likely than those from private schools to rate this style highest (Table 7). Although less than half of the students in either group favour this style, for government students it is approximately equal as a favourite to the Verbal style (just under $40 \%$ of students).

\section{Tactual}

Although the Tactual style is in third place among students in general, certain groups of students tend to favour it more than others. Firstly, like the Visual-Picture style, it is more popular among government school students than among private school students (Table 8). Secondly, Table 9 shows that students' Tactual preference also relates to where they live. The students most in favour of a Tactual style are those from government schools living in less urbanized areas (Ajman, Dubai outside the city, Abu Dhabi off the central island). The next most likely to favour this style are government school graduates living in 
more urban areas (Sharjah, Abu Dhabi city, Dubai city). The least likely to favour the Tactual style are students from private schools, almost all of whom live in central urban areas. Note that for this calculation the small numbers of students from the Emirates of Fujairah, Um Al Qaiwain and Ras Al Khaimah have also been excluded.

Since the Tactual preference is less common among private school students and these students' GPA's tend to be higher, Tactual preference is naturally lower among higher-GPA students overall. However, in this case there is a significant relationship even within the private school group: private school students with a greater Tactual preference tend to have a lower GPA than those with less Tactual preference (Table 10). No such relation is evident within the government school students; however, interestingly government school students in the General Education program (the largest cohort within our sample) were much more likely than their private school classmates not to know their GPA, which makes it difficult to calculate for this group.

\section{Psychological styles}

In this section we consider the psychological elements of the learning styles model. The $B E$ tests for two dimensions of psychological 'thinking style':

Reflective (e.g. I prefer to take time and think before I answer a question) vs. Impulsive (e.g. I tend to answer questions quickly and move on).

and

Analytic (e.g. I prefer to use a systematic approach when solving problems) vs. Global (e.g. I usually prefer less detail about a task before I begin)

Unlike the perceptual styles, each of these dimensions has two contrasting poles. Thus on the Reflective/Impulsive scale, -100 indicates a very Reflective approach, and +100 a very Impulsive approach. On the Analytic/Global scale a score of -100 indicates a very Analytic approach, and +100 a very Global approach.

\section{Overall profile}

Figure 4 shows the percentage of students who were moderately or strongly Reflective or Impulsive, as well as mixed responses. The majority of students appear not to be strongly oriented in either direction, but more than a third of them are assessed as taking a Reflective approach, while just $6.7 \%$ of students appear to favour an Impulsive approach. Note that a Reflective approach to learning may be related to a local cultural expectation for people (and especially women) to pause before speaking in public contexts. 
Figure 4: Percentage of students: Reflective vs. Impulsive.

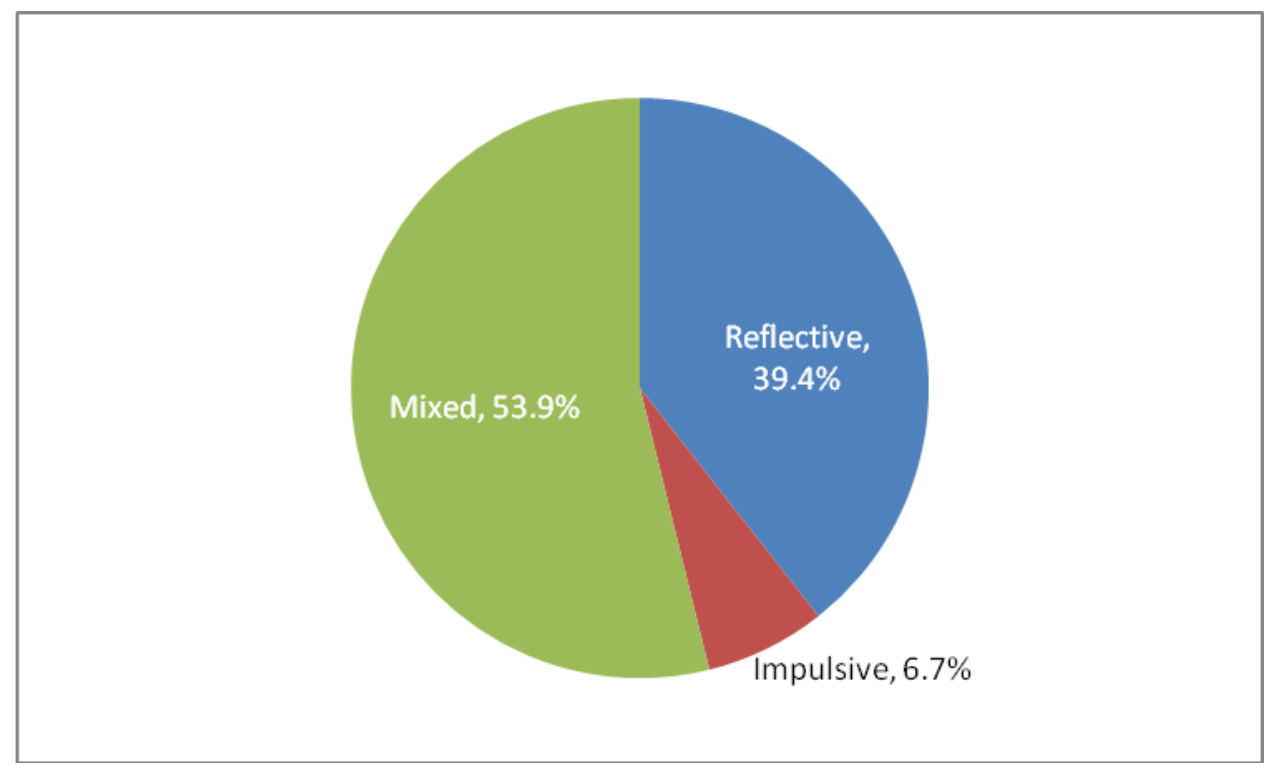

Figure 5 below shows the percentage of students who were moderately to strongly Analytic or Global, and those who gave mixed responses. Again the majority of students are mixed in their responses; a quarter of them take an Analytic approach (perhaps reflecting a Left-brain bias linked also to the preference for a Verbal style - see above); very few appear to favour a Global approach as assessed by the $B E$.

Figure 5: Percentage of students: Analytic/Global.

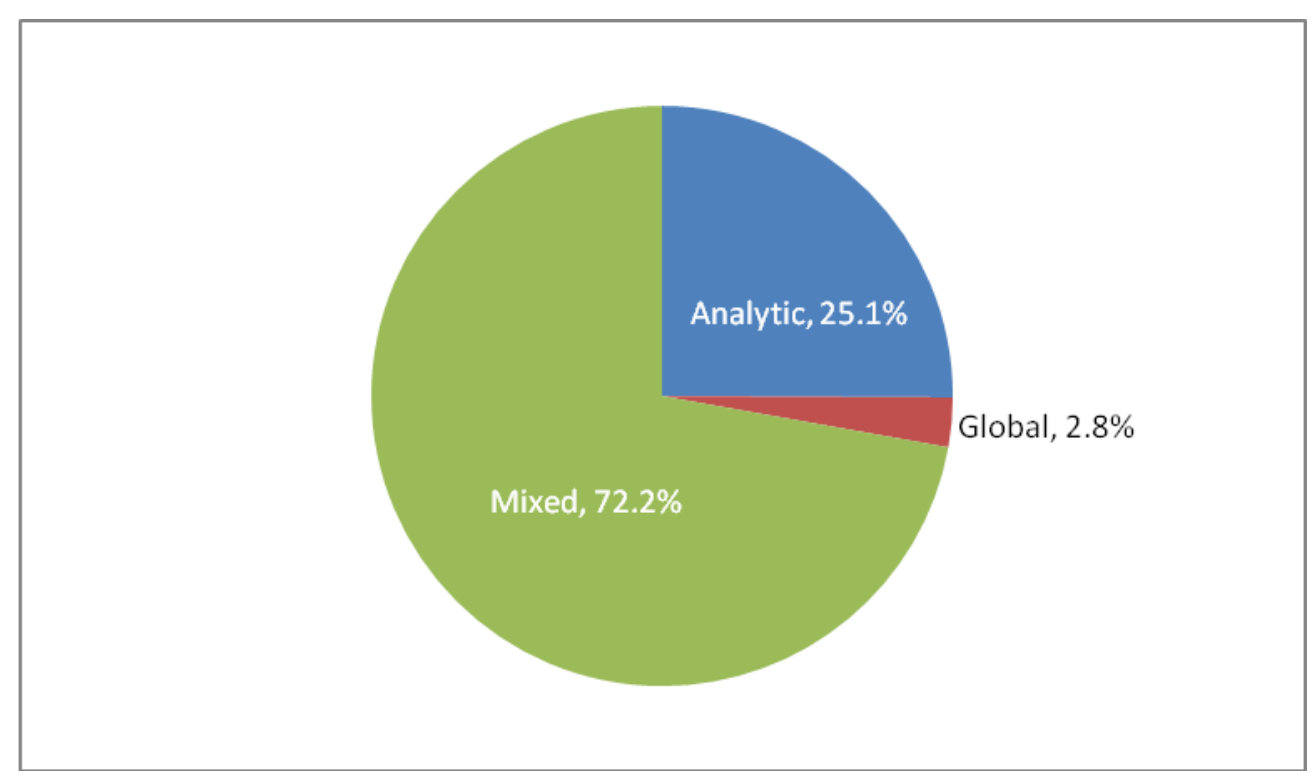

The mean scores for both dimensions are, not surprisingly, within the "mixed/neutral" band: -21.3 for Reflective/Impulsive and -13.3 for Analytic/Global; and the variation among students is somewhat 
smaller than for the perceptual styles: Standard Deviation 33.7 for Reflective/Impulsive and 20.6 for Analytic/Global.

\section{Psychological style patterns within the student sample}

\section{Reflective/Impulsive}

As noted above, somewhat over half of the students gave mixed responses to this dimension, but a sizeable minority (39.4\%) tended towards the Reflective end, with the remainder assessed as Impulsive. Dividing the students by high school type, each group of students shows this same general pattern; however, the minority of Impulsive learners is significantly greater among private school students as compared with the government school students (Table 11). Among the government school students, on the other hand, there are more Reflective responses (43.4\% of the total sample) and fewer in the other categories, such that the "mixed" responses constitute only just over half of the students $(51.7 \%$ of the total sample). The larger number of Impulsive learners among the private school students may, like the tendency to Verbal learning (see above) reflect a greater opportunity/tolerance for verbalizing by students in private schools. However, it seems that these Impulsive private school students have lower GPA's than their fellow private school students who take a Reflective approach (Table 12).

\section{Analytic/Global}

We have been unable to find a statistically significant relation between the Analytic/Global dimension and any of the demographic items in this study: thus the overall profile described above may well apply across the whole sample. Calculation in this area is made difficult by the overwhelming tendency for students to avoid the "Global" end of the scale. There is some suggestion that students taking an Analytic approach may have a higher GPA, but this does not quite reach significance levels.

\section{Other styles and variables}

Note that the less popular perceptual preferences (Auditory and Kinesthetic), like Analytic/Global, did not show a significant relation with school type or other variables. Also some variables which we had expected to be related to learning style appeared not to be in this study; for example there was not a clear relation between number of semesters studied and perceptual/psychological elements of learning style, suggesting that students' learning styles do not change in a systematic way as they progress through the university (cf. Dunn \& Griggs, 2000). Students' registered major also did not show an independent relation with learning style although, like number of terms in Readiness, its close relation with high school type (private school students tended to be majoring in Business or Communication rather than in Education or Information Technology) means that it has some statistical relation with some learning style elements. This variable was more difficult to analyze in this sample because of the preponderance of (non-majoring) General Education students and Business majors.

Mother's level of education was also not significantly related to any of the perceptual or psychological learning style elements in this study, despite the fact that it is related to school type: the more educated a student's mother is, the more likely the student herself is to have attended a private school, see Table 13.

\section{Conclusion}

The findings above suggest that ZU students are varied in their preferred perceptual learning styles, and that favourite learning styles of at least half of them are other than the Auditory, Visual-word and Visual- 
picture styles which are addressed in classic lecturing with graphic support. These teaching methods are often effective, and address the favourite learning styles of approximately half of ZU students. However, it is worth considering a wider range of methods.

The Verbal style (learning by talking) is the most favoured one among these students, and supplementing lectures and graphics with discussion (or even self-verbalizing tasks) could help more students to benefit from instruction. It would also be worthwhile to explore teaching strategies addressing the Tactual style, especially as this style appears to be more common among students from less economically/academically advantaged backgrounds. Indeed, if a wider range of learning styles were catered to in the education system, it is possible that education would become accessible to a greater range of students and in the long term the overall profile of the students would change. It is worth noting that learning in a Visual-word mode (reading) is a minority pursuit among ZU students, so reading in academic study may need to be supported (although not replaced or duplicated) by material using other channels of communication and instruction.

Since Verbal is particularly popular among students coming from private schools, these students are more likely to benefit from discussion activities. Students from government schools, on the other hand, may tend to prefer a Visual-picture style of presentation. Teachers may bear this in mind when teaching, particularly in majors where one or the other group of students predominates. For example, in a ZU Business or Communication class there may be a sizeable and articulate group of students from private schools who thrive on verbal expression, while monitoring and support may be needed for those who prefer a Visual-picture style.

An interesting issue which arose from the analysis of this data is the pervasiveness of the government/private school distinction, which is related to other variables including mother's level of education, length of time spent in the Readiness program, and GPA attainment. It seems likely that these variables all indicate an underlying variable of socio-economic status which would be worth investigating in future research.

\section{Recommendations for building and implementing successful learning style based programs}

To establish a strong awareness and successful programs of learning styles institutions should start by building a Learning Styles Inventory Database (LSID).

a) Choose, prepare and adapt a sound learning style assessment instrument:

- Translate and adapt inventory instrument to better fit local students.

- Introduce important demographic, social and cultural variables of interest to your country or district into the instrument.

- Pilot the instrument in few government schools (and possibly private schools) in each educational zone or district.

- Evaluate and refine.

b) Profiling students and building your LSID:

- Profile most or all university students if possible.

- Enter and organize data in MS Excel and/or SPSS. 
- Make available individual and group LS profiles to share with students, teachers and administrators.

c) Training:

- Train teachers, students and administrators in understanding various elements of learning style model, as well as reading and interpreting learning style profiles and related prescribed instructional strategies.

- Train teachers and students on methods of building learning styles resources.

- Train teachers on learning style-matched instructions.

d) Research and Experimentation:

Use the available LSID to perform statistical analyses:

- Comparative research: e.g. comparing LS of different emirates and the LS of UAE students against students of different countries like the USA.

- Correlational research: investigate the relationship between social variable (e.g. gender) and different elements of learning styles (e.g. auditory/visual/kinesthetic).

- Experimental research: investigate the effect of LS instructional strategies on student academic performance in many subject areas like math, science and English.

Learning Style-based education holds high promise to improve the process of educational reform and research in higher education in the Gulf Region, moving traditional educational practices from teacherto student-centered. For the first time we will be able to develop and build significant learning style inventory databases related to our students and countries. An important aspect of these inventories is their ability to clearly describe individual and group profiles. In addition, they are able to support recommendations on study and instructional strategies important in guiding students, teachers, parents and others to maximize learning. Most significantly, it will empower students and help them take charge of their own learning and study. Each student can read his/her own learning style profile report with a description of how to use it and benefit from it. Teachers can use resources more responsive to their students learning styles and needs. Parents can show more understanding to their children's needs by creating stimulating environments that better suit them. Administrators and curriculum developers can use learning style data and research findings to redesign syllabi that cater for differentiated learning. Finally, a word of wisdom is in order: It is morally wrong to let our students suffer as a result of a mismatched instruction that does not take their needs and cultural attributes into consideration.

\section{Acknowledgements}

The authors would like to thank Kate O'Neill, Susan Rundle, Andrea Honigsfeld and all the Zayed University faculty and students who facilitated the administration of this survey.

\section{References}

Arden-Close C. (1999). Conflict of Learning Styles: University Science Lectures in the Sultanate of Oman: The student experience. Journal of Science Education and Technology, Springer Netherlands, Volume 8, Number 4, (pp. 323-332). 
Bahoora, F. (1996). The cognitive and learning styles of Arabic students in American middle schools: The Southeast Michigan Experience. Doctoral Dissertation, UMI Anne Arbor, MI.

Boyle, R. A. \& Dunn, R. (1998). Teaching law students through individual learning styles. Albany Law Review, 62(1), 213-255.

Burke, K. \& Dunn, R. (2002). Teaching math effectively to elementary students. Academic Exchange Quarterly, 6(1).

Dunn, R. \& Dunn, K. (1972). Practical approaches to individualizing instruction: Contracts and other effective teaching strategies. Englewood Cliffs, NJ: Parker Publishing Division of Prentice Hall.

Dunn, R. \& Dunn, K. (1978). Teaching students through their individual learning styles: A practical approach. Reston, VA: Prentice Hall.

Dunn, R. \& Dunn, K. (1992). Teaching elementary students through their individual learning styles: Practical approaches for grades 3-6. Boston, MA: Allyn \& Bacon.

Dunn, R. \& Dunn, K. (1993). Teaching secondary students through their individual learning styles: Practical approaches for grades 7-12. Boston, MA: Allyn \& Bacon.

Dunn, R. \& Dunn, K. (1999). The complete guide to the learning styles in-service system. Boston, MA: Allyn \& Bacon.

Dunn, R. \& Griggs, S. (eds., 2000). Practical Approaches to Using Learning Styles in Higher Education. Westport, CT: Bergin \& Garvey.

Dunn, R. \& Honigsfeld, A. (2006). Learning-Style Characteristics for adult Learners In R. Dunn \& S. A. Griggs (Eds.), What if?: Promising Practices for Improving Education (pp. 54-58). Lanham, MD: Rowman \& Littlefield.

Dunn, R. (1989). Can schools overcome the impact to societal ills on student achievement? The research indicates--yes! The Principal, 34(5), 1-15.

Dunn, R. (1997). Everything you need to successfully implement a learning-styles instructional program: Materials and methods. New Wilmington, PA: The Association for the Advancement of International Education.

Entwistle, N.J. \& Hanley, M. (1979). Personality, cognitive style, and students' learning strategies. Higher Education Bulletin, 6 (1) pp. 23-43.

Felder, R.M. \& Silverman, L.K. (1988). Learning and Teaching Styles in Engineering Education. Engineering Education, 78(7), 674-681.

Freire, P. (1973). Education for critical consciousness. New York: Continuum.

Gardner, Howard. (1983) "Frames of Mind: The Theory of Multiple Intelligences." New York: Basic Books. Gregorc, A.F. \& Butler, K.A. (1984). Learning is a matter of style. Vocational Education, 59 (3) pp. 27-29.

Jones, D.J. \& Watson, B.C. (1990). High-Risk Students and Higher Education: Future Trends. ASHE-ERIC Higher Education Report No. 3. George Washington University.

Jung, C.G. (1921). Psychological Types. Collected Works, Volume 6. Princeton, N.J.: Princeton University Press.

Kavale, K. A. \& LeFever, G. B. (2007). Dunn and Dunn model of learning-style preferences: critique of Lovelace meta-analysis. The Journal of Educational Research, 101(2). 
Keefe, J.W. \& Ferrell, B.G. (1990). Developing a defensible learning style paradigm. Educational Leadership, 48 (2) pp. 57-61.

Kolb, D.A. (1984) Experiential Learning: Experience as the Source of Learning and Development. New Jersey, Prentice-Hall Inc.

Komives, S. R. (2003). Student services. San Francisco, CA: Jossey-Bass.

LaMothe, J., Billings, D. M., Belcher, A., Cobb, K., Nice, A. \& Richardson, V. (1991). Reliability and validity of the Productivity Environmental Preference Survey (PEPS). Nurse Educator, 16(4), 30-35.

Myers-Briggs I. \& McCaulley M. H., (1985): Manual: A Guide to the Development and Use of the Myers Briggs Type Indicator. Consulting Psychologists Press, 1985.

Northwestern University (2008). Boys' and girls' brains are different: gender differences in language appear biological. ScienceDaily. Accessed 3 June, 2009 at http://www.sciencedaily.com/releases/2008/03/080303120346.htm

Palfreyman, D. (2006). Social Context and Resources for Language Learning. System 34/3, 352-370.

Palmer, P. (1998). The courage to teach. San Francisco, CA: Jossey-Bass.

Rahal, T. (2009). Profiling Student Learning Styles: Improving the Educational Reform Process in the UAE. 3rd International Quality Congress Middle East. Dubai, April 2009.

Reiff, J. C. (1992). Learning styles. Washington, DC: National Education Association.

Renzulli J., Leppien J., \& Hays T. (2000) The Multiple Menu Model: A Practical Guide for Developing Differentiated Curriculum. Creative Learning Press, Inc.

Rundle, S. \& Dunn, R. (1996-2007). Building Excellence Survey.

http://www.learningstyles.net/index.php?option=com_content\&task=view\&id=25\&ltemid=78

Terenzini, P. \& Pascarella, E. (1994). Living with myths: Undergraduate education in America. Change 28, 28-32.

Whitefield, D. (1995). Learning styles - great minds don't think alike. Proceedings of the 4th Annual

Teaching Learning Forum. Edith Cowan University. Accessed 3 June, 2009 at

http://otl.curtin.edu.au/tlf/tlf1995/whitefield.html

\section{Authors}

Dr. Tofi Rahal holds two Masters degrees \& a Doctorate degree in Science and Mathematics Education from Columbia University, USA. He is a specialist in Learning Style-Based Education \& the building of differentiated multi-sensory instructional packages. He has extensive experience in educational technology and has served as the President of the Educational Technology committee at the UAE Ministry of Education. In addition Dr. Rahal has has conducted numerous research activities on student motivation and quantitative reasoning. He also has experience in teaching ESL, and served for two years as the liaison between TESOL Arabia and the UAE Ministry of Education. He has written in professional journals and presented extensively at conferences around the world, including that of the League of Arab States on Human Development.

Dr. David Palfreyman is currently Assistant Professor in the Department of Languages at Zayed University, UAE. He has twelve years' experience of teaching and contributing to faculty and curriculum development in the UAE. He holds a PhD in Language Studies and an MA in Language in the 
Multicultural Community. He has published several articles in the field of language and university education, and co-edited two collections, Learner Autonomy Across Cultures and Learning and Teaching Across Cultures in Higher Education, both published by Palgrave Macmillan. 


\title{
Appendix 1
}

\section{Introductory presentation for survey administration}

\section{LEARNING STYLES}

\author{
$\&$ \\ The BE survey
}

Complete this sentence:

"I learn best when..." 


\section{Everyone learns in a different way...}

Some people prefer to learn from pictures, other people prefer to learn by listening.

Some people prefer to study at a desk; others prefer to study on a couch or on the floor.

Some people prefer to study in a quiet place; others prefer to study while listening to music.

Some people enjoy learning; other people want most of all to get high grades.

Some people can learn many new things at the same time, other people prefer to learn one thing at a time.

\section{The Building Excellence survey...}

A lot of questions (124), but all short and simple.

1. I like learning with friends rather than alone.

\begin{tabular}{ccccc}
$\begin{array}{c}\text { Strongly } \\
\text { Disagree }\end{array}$ & Disagree & $\begin{array}{c}\text { Neither } \\
\text { Agree nor } \\
\text { Disagree }\end{array}$ & Agree & $\begin{array}{c}\text { Strongly } \\
\text { Agree }\end{array}$ \\
\hline & 0 & 0 & 0 & 0 \\
\hline
\end{tabular}

2. I don't like studying in the morning.

\begin{tabular}{ccccc}
$\begin{array}{c}\text { Strongly } \\
\text { Disagree }\end{array}$ & Disagree & $\begin{array}{c}\text { Neither } \\
\text { Agree nor } \\
\text { Disagree }\end{array}$ & Agree & $\begin{array}{c}\text { strongly } \\
\text { Agree }\end{array}$ \\
\hline & 0 & 0 & 0 & 0 \\
\hline
\end{tabular}

If you don't understand a word, what can you do? 


\section{1) Go to this page:}

\section{www. learningstyles.net}

\section{Then click}

Create An Account at the top:

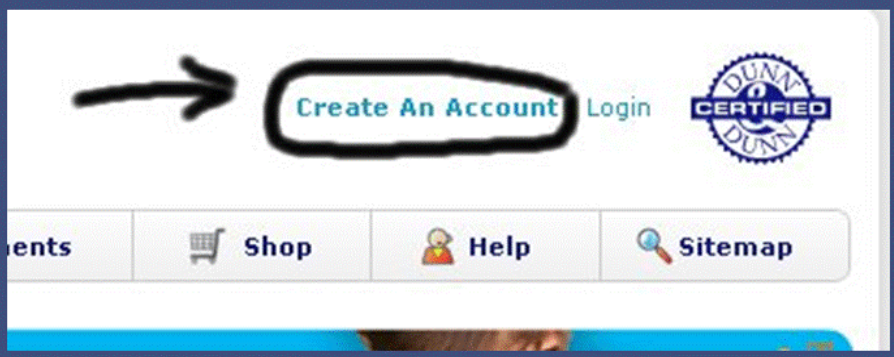

\section{2) Use your ZU e-mail address and any password of YOUR choice then click SUBMIT}

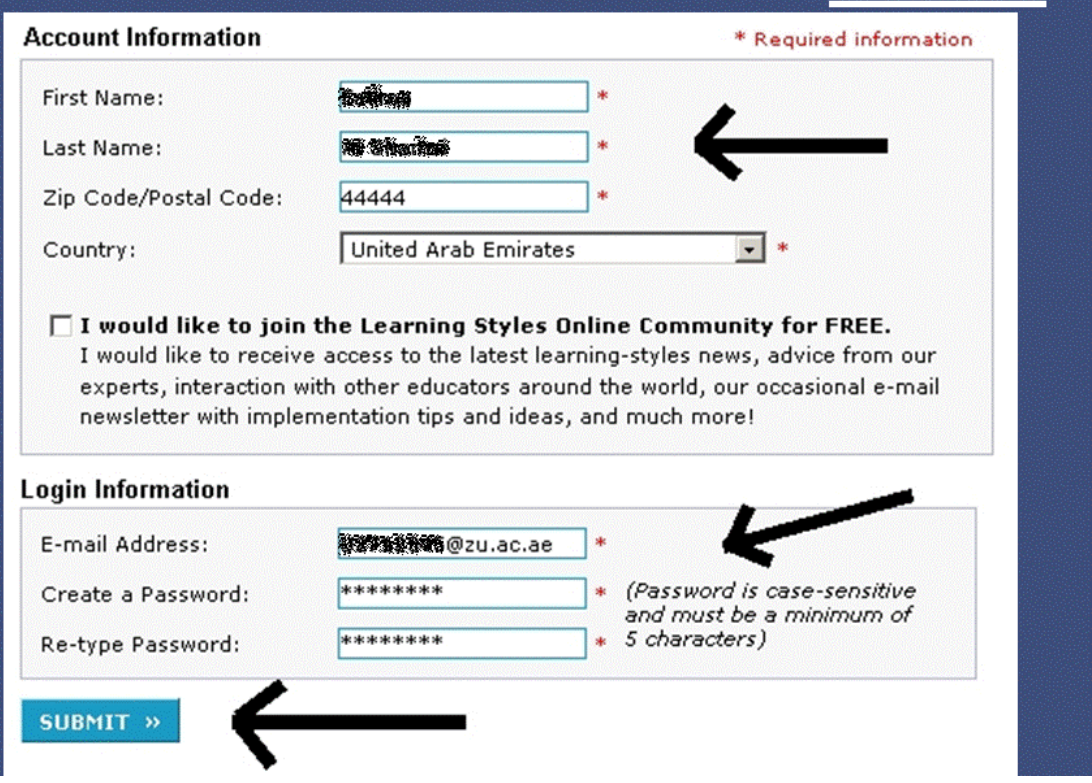




\section{3) Mouse over Assessments at the top,}

then click BE in the list:

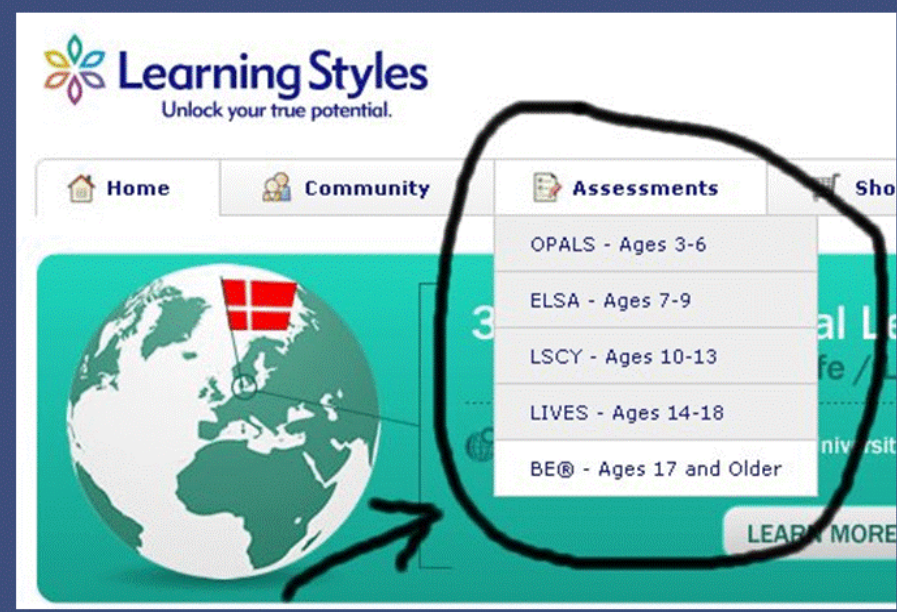

4) Below Take the BE Survey select your language (English) and then click the LAUNCH SURVEY button:

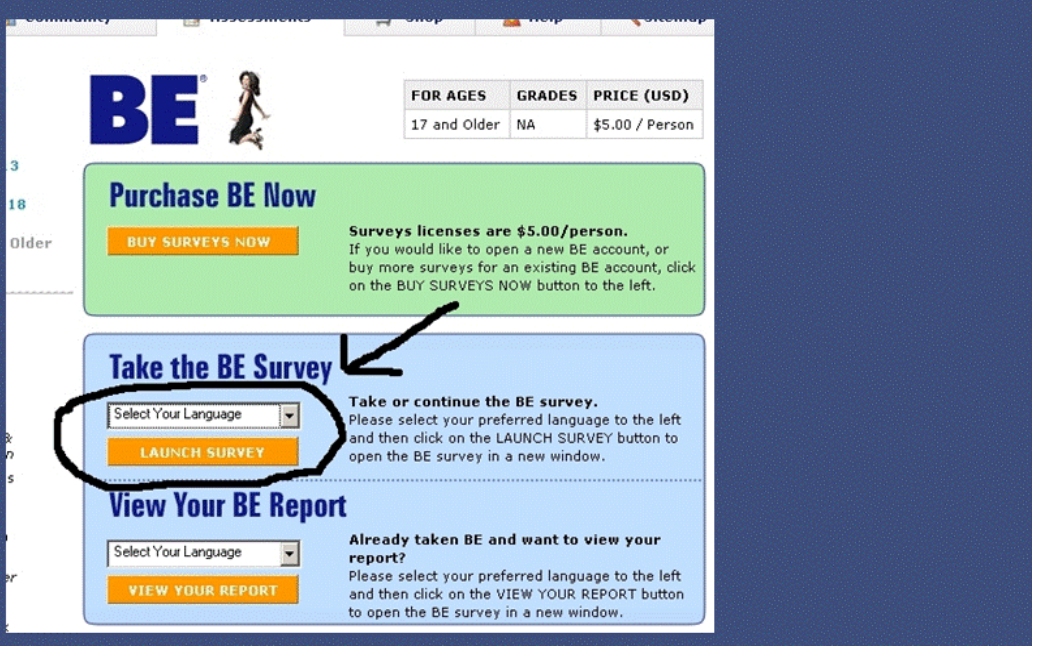




\title{
5) In the blue welcome screen enter the
} Account Code

\author{
then click Next
}

6) Answer the questions about yourself. Occupation $=$ Other, and write student. Educational Background $=$ High School Graduate

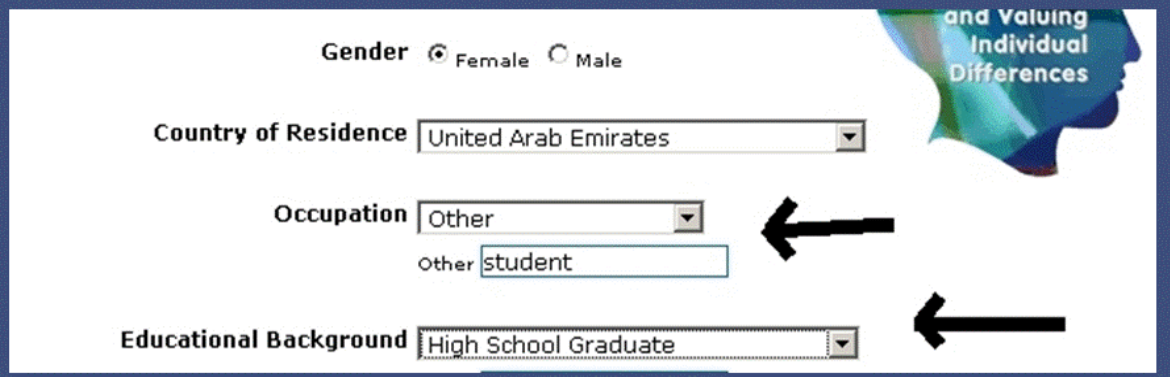

\section{When you have finished answering the questions, click CONTINUE to take the learning styles survey.}




\section{Appendix 2}

\section{Total numbers of students responding in each category}

NB: responses marked with * were removed from relevant calculations because the number of responses was too small to draw reliable conclusions. For two questions comparison data is shown for the 2008 intake of new students to the university.

\section{Where do you live?}

\begin{tabular}{|l|l|}
\hline Abu Dhabi (on the island) & 142 \\
\hline Abu Dhabi (off the island) & 70 \\
\hline Ajman & 28 \\
\hline Dubai (city) & 383 \\
\hline Dubai (outside the city) & 25 \\
\hline Fujairah* & 2 \\
\hline RAK* & 4 \\
\hline Sharjah & 61 \\
\hline UAQ* & 11 \\
\hline
\end{tabular}

What kind of high school did you graduate from?

\begin{tabular}{|l|l|l|}
\hline Government School & 447 & (62\% of sample, compared with $74 \%$ of 2008 intake) \\
\cline { 1 - 2 } Private School & 279 & (38\% of sample, compared with $25 \%$ of 2008 intake)
\end{tabular}

What was the main language at your high school?

\begin{tabular}{|l|l|}
\hline Arabic & 483 \\
\hline English & 242 \\
\hline
\end{tabular}

How long did you study in Readiness (ABP)?

\begin{tabular}{|c|c|c|}
\hline I entered Colloquy without studying Readiness & 180 & \multirow[t]{5}{*}{$\begin{array}{l}\text { ( } 25 \% \text { of sample, compared with } \\
20 \% \text { of } 2008 \text { intake) }\end{array}$} \\
\hline I studied 1 or 2 terms in Readiness and then entered Colloquy & 251 & \\
\hline I studied 3 or 4 terms in Readiness and then entered Colloquy & 187 & \\
\hline I studied 5 or 6 terms in Readiness then entered Colloquy & 67 & \\
\hline I studied 7 or 8 terms in Readiness then entered Colloquy & 41 & \\
\hline
\end{tabular}


Which semester are you in now (*after* Readiness)?

\begin{tabular}{|l|l|}
\hline First/second semester & 384 \\
\hline Third/fourth semester & 154 \\
\hline Fifth/sixth semester & 154 \\
\hline Seventh/eighth semester & 16 \\
\hline
\end{tabular}

What is your present GPA (Grade Point Average)?

\begin{tabular}{|l|l|}
\hline Between 1.0 and 1.9 & 72 \\
\hline Between 2.0 and 2.9 & 335 \\
\hline Between 3.0 and 4.0 & 198 \\
\hline I don't know & 121 \\
\hline
\end{tabular}

What level of education did your mother finish?

\begin{tabular}{|l|l|}
\hline None & 53 \\
\hline Primary School & 242 \\
\hline High School & 199 \\
\hline College/University & 214 \\
\hline
\end{tabular}

Are you registered for a major?

\begin{tabular}{|l|l|}
\hline No & 308 \\
\hline Yes - Art and Design* & 13 \\
\hline Yes - Business & 245 \\
\hline Yes - Communication and Media & 68 \\
\hline Yes - Education & 44 \\
\hline Yes - Health Sciences* & 13 \\
\hline Yes - Information Technology & 29 \\
\hline Yes - Social and Behavioral Sciences* & 6 \\
\hline
\end{tabular}

Which campus do you study at?

\begin{tabular}{|l|l|}
\hline Abu Dhabi & 213 \\
\hline Dubai & 512 \\
\hline
\end{tabular}




\section{Appendix 3}

\section{Cross-tabulation tables}

Table 5: Cross-tabulation: High School Type * Verbal as favourite style.

\begin{tabular}{|c|c|c|c|c|c|}
\hline & & & Verbal & & \\
\hline & & & No & Yes & Total \\
\hline HighSchoolType & Government School & Count & 269 & 178 & 447 \\
\hline & & $\%$ within HighSchoolType & $60.2 \%$ & $39.8 \%$ & $100.0 \%$ \\
\hline & Private School & Count & 127 & 152 & 279 \\
\hline & & $\%$ within HighSchoolType & $45.5 \%$ & $54.5 \%$ & $100.0 \%$ \\
\hline & Total & Count & 396 & 330 & 726 \\
\hline & & \% within HighSchoolType & $54.5 \%$ & $45.5 \%$ & $100.0 \%$ \\
\hline
\end{tabular}

Chi-Square Tests

\begin{tabular}{|l|l|l|l|l|l|}
\hline & Value & df & $\begin{array}{l}\text { Asymp. Sig. (2- } \\
\text { sided) }\end{array}$ & $\begin{array}{l}\text { Exact Sig. } \\
\text { (2-sided) }\end{array}$ & $\begin{array}{l}\text { Exact Sig. } \\
\text { (1-sided) }\end{array}$ \\
\hline Pearson Chi-Square & 14.889 & 1 & .000 & & \\
Continuity Correction & 14.304 & 1 & .000 & & \\
Likelihood Ratio & 14.891 & 1 & .000 & .000 & .000 \\
Fisher's Exact Test & 726 & & & & \\
N of Valid Cases & 726 & & & & \\
\hline
\end{tabular}


Table 6: Cross-tabulation, private school students only: High School Language * Verbal as favourite style.

\begin{tabular}{|c|c|c|c|c|c|}
\hline & & & \multicolumn{3}{|l|}{ Verbal } \\
\hline & & & No & Yes & Total \\
\hline \multirow[t]{6}{*}{ HighSchoolLang } & \multirow[t]{2}{*}{ Arabic } & Count & 22 & 27 & 49 \\
\hline & & \% within HighSchoolLang & $44.9 \%$ & $55.1 \%$ & $100.0 \%$ \\
\hline & \multirow[t]{2}{*}{ English } & Count & 105 & 125 & 230 \\
\hline & & \% within HighSchoolLang & $45.7 \%$ & $54.3 \%$ & $100.0 \%$ \\
\hline & \multirow[t]{2}{*}{ Total } & Count & 127 & 152 & 279 \\
\hline & & \% within HighSchoolLang & $45.5 \%$ & $54.5 \%$ & $100.0 \%$ \\
\hline
\end{tabular}

\section{Chi-Square Tests}

\begin{tabular}{|l|l|l|l|l|l|}
\hline & Value & df & $\begin{array}{l}\text { Asymp. Sig. } \\
\text { (2-sided) }\end{array}$ & $\begin{array}{l}\text { Exact Sig. } \\
\text { (2-sided) }\end{array}$ & $\begin{array}{l}\text { Exact Sig. } \\
\text { (1-sided) }\end{array}$ \\
\hline Pearson Chi-Square & .009 & 1 & .923 & & \\
Continuity Correction & .000 & 1 & 1.000 & \\
Likelihood Ratio & .009 & 1 & .923 & 1.000 & .526 \\
Fisher's Exact Test & & & & & \\
N of Valid Cases & 279 & & & & \\
\hline
\end{tabular}

Table 7: Cross-tabulation: High School Type * Visual-Picture as favourite style.

\begin{tabular}{|lll|l|l|l|}
\hline & & \multicolumn{2}{l|}{ Visual Picture } \\
\cline { 3 - 6 } & & No & Yes & Total \\
\hline HighSchoolType & Government School & Count & 273 & 174 & 447 \\
& & $\%$ within HighSchoolType & $61.1 \%$ & $38.9 \%$ & $100.0 \%$ \\
\cline { 2 - 6 } & Private School & Count & 206 & 73 & 279 \\
& \% within HighSchoolType & $73.8 \%$ & $26.2 \%$ & $100.0 \%$ \\
\cline { 2 - 6 } & Total & Count & 479 & 247 & 726 \\
& \% within HighSchoolType & $66.0 \%$ & $34.0 \%$ & $100.0 \%$ \\
\hline
\end{tabular}

\section{Chi-Square Tests}

\begin{tabular}{|l|l|l|l|l|l|}
\hline & Value & df & $\begin{array}{l}\text { Asymp. Sig. } \\
\text { (2-sided) }\end{array}$ & $\begin{array}{l}\text { Exact Sig. } \\
\text { (2-sided) }\end{array}$ & $\begin{array}{l}\text { Exact Sig. } \\
\text { (1-sided) }\end{array}$ \\
\hline Pearson Chi-Square & 12.463 & 1 & .000 & & \\
Continuity Correction & 11.900 & 1 & .001 & & \\
Likelihood Ratio & 12.707 & 1 & .000 & .000 & .000 \\
Fisher's Exact Test & 726 & & & & \\
N of Valid Cases & 726 & & & & \\
\hline
\end{tabular}


Table 8: Cross-tabulation: High School Type * Tactual as favourite style.

\begin{tabular}{|c|c|c|c|c|c|}
\hline & & & \multicolumn{3}{|c|}{ Tactual } \\
\hline & & & No & Yes & Total \\
\hline \multirow[t]{6}{*}{ HighSchoolType } & \multirow[t]{2}{*}{ Government School } & Count & 325 & 122 & 447 \\
\hline & & \% within HighSchoolType & $72.7 \%$ & $27.3 \%$ & $100.0 \%$ \\
\hline & \multirow[t]{2}{*}{ Private School } & Count & 231 & 48 & 279 \\
\hline & & \% within HighSchoolType & $82.8 \%$ & $17.2 \%$ & $100.0 \%$ \\
\hline & \multirow[t]{2}{*}{ Total } & Count & 556 & 170 & 726 \\
\hline & & \% within HighSchoolType & $76.6 \%$ & $23.4 \%$ & $100.0 \%$ \\
\hline
\end{tabular}

Chi-Square Tests

\begin{tabular}{|l|l|l|l|l|l|}
\hline & Value & df & $\begin{array}{l}\text { Asymp. Sig. (2- } \\
\text { sided) }\end{array}$ & $\begin{array}{l}\text { Exact Sig. (2- } \\
\text { sided) }\end{array}$ & $\begin{array}{l}\text { Exact Sig. (1- } \\
\text { sided) }\end{array}$ \\
\hline Pearson Chi-Square & 9.750 & 1 & .002 & & \\
Continuity Correction & 9.195 & 1 & .002 & & \\
Likelihood Ratio & 10.053 & 1 & .002 & .002 & .001 \\
Fisher's Exact Test & & & & & \\
N of Valid Cases & 726 & & & & \\
\hline
\end{tabular}

Table 9: Cross-tabulation: Place of Residence * Tactual as favourite style * High School Type

\begin{tabular}{|c|c|c|c|c|c|c|}
\hline \multirow{2}{*}{\multicolumn{2}{|c|}{ HighSchoolType }} & & & \multicolumn{3}{|c|}{ Tactual } \\
\hline & & & & \multirow{3}{*}{$\begin{array}{l}\text { No } \\
42 \\
64.6 \%\end{array}$} & \multirow{3}{*}{\begin{tabular}{|l} 
Yes \\
23 \\
$35.4 \%$
\end{tabular}} & \multirow{3}{*}{\begin{tabular}{|l} 
Total \\
65 \\
$100.0 \%$
\end{tabular}} \\
\hline \multirow{14}{*}{$\begin{array}{l}\text { Government } \\
\text { School }\end{array}$} & \multirow[t]{14}{*}{ Wherelive } & \multirow[t]{2}{*}{ Abu Dhabi (off the island } & Count & & & \\
\hline & & & $\%$ within WhereLive & & & \\
\hline & & \multirow[t]{2}{*}{ Abu Dhabi (on the island) } & Count & 54 & 20 & 74 \\
\hline & & & $\%$ within WhereLive & $73.0 \%$ & $27.0 \%$ & $100.0 \%$ \\
\hline & & \multirow[t]{2}{*}{ Ajman } & Count & 14 & 12 & 26 \\
\hline & & & $\%$ within WhereLive & $53.8 \%$ & $46.2 \%$ & $100.0 \%$ \\
\hline & & \multirow[t]{2}{*}{ Dubai (city) } & Count & 160 & 41 & 201 \\
\hline & & & \% within WhereLive & $79.6 \%$ & $20.4 \%$ & $100.0 \%$ \\
\hline & & \multirow[t]{2}{*}{ Dubai (outside the city) } & Count & 8 & 5 & 13 \\
\hline & & & $\%$ within WhereLive & $61.5 \%$ & $38.5 \%$ & $100.0 \%$ \\
\hline & & \multirow[t]{2}{*}{ Sharjah } & Count & 37 & 18 & 55 \\
\hline & & & \% within WhereLive & $67.3 \%$ & $32.7 \%$ & $100.0 \%$ \\
\hline & & \multirow[t]{2}{*}{ Total } & Count & 315 & 119 & 434 \\
\hline & & & $\%$ within WhereLive & $72.6 \%$ & $27.4 \%$ & $100.0 \%$ \\
\hline
\end{tabular}




\begin{tabular}{|c|c|c|c|c|c|}
\hline \multirow[t]{7}{*}{ Private School WhereLive } & Abu Dhabi (off the island & $\begin{array}{l}\text { Count } \\
\% \text { within WhereLive }\end{array}$ & $\begin{array}{l}5 \\
100.0 \%\end{array}$ & $\begin{array}{l}0 \\
.0 \%\end{array}$ & $\begin{array}{l}5 \\
100.0 \%\end{array}$ \\
\hline & Abu Dhabi (on the island) & $\begin{array}{l}\text { Count } \\
\% \text { within WhereLive }\end{array}$ & $\begin{array}{l}57 \\
83.8 \%\end{array}$ & $\begin{array}{l}11 \\
16.2 \%\end{array}$ & $\begin{array}{l}68 \\
100.0 \%\end{array}$ \\
\hline & Ajman & $\begin{array}{l}\text { Count } \\
\% \text { within WhereLive }\end{array}$ & $\begin{array}{l}2 \\
100.0 \%\end{array}$ & $\begin{array}{l}0 \\
.0 \%\end{array}$ & $\begin{array}{l}2 \\
100.0 \%\end{array}$ \\
\hline & Dubai (city) & $\begin{array}{l}\text { Count } \\
\% \text { within WhereLive }\end{array}$ & $\begin{array}{l}149 \\
81.9 \%\end{array}$ & $\begin{array}{l}33 \\
18.1 \%\end{array}$ & $\begin{array}{l}182 \\
100.0 \%\end{array}$ \\
\hline & Dubai (outside the city) & $\begin{array}{l}\text { Count } \\
\% \text { within WhereLive }\end{array}$ & $\begin{array}{l}10 \\
83.3 \%\end{array}$ & $\begin{array}{l}2 \\
16.7 \%\end{array}$ & $\begin{array}{l}12 \\
100.0 \%\end{array}$ \\
\hline & Sharjah & $\begin{array}{l}\text { Count } \\
\% \text { within WhereLive }\end{array}$ & $\begin{array}{l}4 \\
66.7 \%\end{array}$ & $\begin{array}{l}2 \\
33.3 \%\end{array}$ & $\begin{array}{l}6 \\
100.0 \%\end{array}$ \\
\hline & Total & $\begin{array}{l}\text { Count } \\
\% \text { within WhereLive }\end{array}$ & $\begin{array}{l}227 \\
82.5 \%\end{array}$ & $\begin{array}{l}48 \\
17.5 \%\end{array}$ & $\begin{array}{l}275 \\
100.0 \%\end{array}$ \\
\hline
\end{tabular}

Chi-Square Tests

\begin{tabular}{|ll|l|l|l|}
\hline HighSchoolType & & Value & df & Asymp. Sig. (2-sided) \\
\hline Government School & Pearson Chi-Square & 13.218 & 5 & .021 \\
& Likelihood Ratio & 12.897 & 5 & .024 \\
& N of Valid Cases & 434 & & \\
\hline Private School & Pearson Chi-Square & $2.670^{\mathrm{a}}$ & 5 & .751 \\
& Likelihood Ratio & 3.705 & 5 & .593 \\
& N of Valid Cases & 275 & & \\
\hline
\end{tabular}

a. 7 cells (58.3\%) have expected count less than 5 . The minimum expected count is .35 .

Table 10: Cross-tabulation, private school students only: Present GPA (excluding "I don't know") * Tactual as favourite style.

\begin{tabular}{|c|c|c|c|c|c|c|}
\hline \multirow{2}{*}{\multicolumn{2}{|c|}{ HighSchoolType }} & & & \multicolumn{3}{|c|}{ Tactual } \\
\hline & & & & \multirow{2}{*}{$\frac{\text { No }}{20}$} & \multirow{2}{*}{\begin{tabular}{|l|} 
Yes \\
12
\end{tabular}} & \multirow{2}{*}{\begin{tabular}{|l|} 
Total \\
32
\end{tabular}} \\
\hline \multirow{8}{*}{ Private School } & \multirow{8}{*}{ PresentGPA } & \multirow{2}{*}{ Between 1.0 and 1.9} & Count & & & \\
\hline & & & $\%$ within PresentGPA & $62.5 \%$ & $37.5 \%$ & $100.0 \%$ \\
\hline & & \multirow{2}{*}{ Between 2.0 and 2.9} & Count & 94 & 20 & 114 \\
\hline & & & $\%$ within PresentGPA & $82.5 \%$ & $17.5 \%$ & $100.0 \%$ \\
\hline & & \multirow{2}{*}{ Between 3.0 and 4.0} & Count & 82 & 11 & 93 \\
\hline & & & $\%$ within PresentGPA & $88.2 \%$ & $11.8 \%$ & $100.0 \%$ \\
\hline & & \multirow{2}{*}{ Total } & Count & 196 & 43 & 239 \\
\hline & & & $\%$ within PresentGPA & $82.0 \%$ & $18.0 \%$ & $100.0 \%$ \\
\hline
\end{tabular}


Chi-Square Tests

\begin{tabular}{|ll|l|l|l|}
\hline \multicolumn{2}{|l|}{ HighSchoolType } & Value & df & $\begin{array}{l}\text { Asymp. Sig. } \\
\text { (2-sided) }\end{array}$ \\
\hline \multirow{2}{*}{ Government School } & $\begin{array}{l}\text { Pearson Chi-Square } \\
\text { Likelihood Ratio }\end{array}$ & 1.662 & 2 & .436 \\
& N of Valid Cases & 366 & 2 & .426 \\
\hline \multirow{2}{*}{$\begin{array}{llll}\text { Private School } \\
\text { Pearson Chi-Square }\end{array}$} & 10.664 & 2 & .005 \\
& Likelihood Ratio & 9.433 & 2 & .009 \\
& N of Valid Cases & 239 & & \\
\hline
\end{tabular}

Table 11: Cross-tabulation: Reflective/Impulsive (excluding "mixed") * High School Type.

\begin{tabular}{|c|c|c|c|c|c|}
\hline & & & \multicolumn{3}{|c|}{ Refleclmpuls } \\
\hline & & & Impuls & Reflec & Total \\
\hline \multirow[t]{6}{*}{ HighSchoolType } & \multirow[t]{2}{*}{ Government School } & Count & 22 & 194 & 216 \\
\hline & & $\%$ within HighSchoolType & $10.2 \%$ & $89.8 \%$ & $100.0 \%$ \\
\hline & \multirow[t]{2}{*}{ Private School } & Count & 27 & 92 & 119 \\
\hline & & \% within HighSchoolType & $22.7 \%$ & $77.3 \%$ & $100.0 \%$ \\
\hline & \multirow[t]{2}{*}{ Total } & Count & 49 & 286 & 335 \\
\hline & & \% within HighSchoolType & $14.6 \%$ & $85.4 \%$ & $100.0 \%$ \\
\hline
\end{tabular}

Chi-Square Tests

\begin{tabular}{|l|l|l|l|l|l|}
\hline & Value & df & $\begin{array}{l}\text { Asymp. Sig. } \\
\text { (2-sided) }\end{array}$ & $\begin{array}{l}\text { Exact Sig. } \\
\text { (2-sided) }\end{array}$ & $\begin{array}{l}\text { Exact Sig. } \\
\text { (1-sided) }\end{array}$ \\
\hline Pearson Chi-Square & 9.607 & 1 & .002 & & \\
Continuity Correction & 8.631 & 1 & .003 & & \\
Likelihood Ratio & 9.209 & 1 & .002 & .003 & .002 \\
Fisher's Exact Test & & & & & \\
N of Valid Cases & 335 & & & & \\
\hline
\end{tabular}


Table 12: Crosstabulation, private school students only: GPA * Reflective/Impulsive (“Mixed” excluded).

\begin{tabular}{|c|c|c|c|c|c|c|}
\hline \multirow[b]{2}{*}{ HighSchoolType } & & & & \multicolumn{3}{|c|}{ Refleclmpuls } \\
\hline & & & & Impuls & Reflec & Total \\
\hline \multirow[t]{8}{*}{ Private School } & PresentGPA & Between 1.0 and 1.9 & Count & 7 & 7 & 14 \\
\hline & & & $\%$ within Refleclmpuls & $29.2 \%$ & $8.9 \%$ & $13.6 \%$ \\
\hline & & Between 2.0 and 2.9 & Count & 10 & 37 & 47 \\
\hline & & & $\%$ within Refleclmpuls & $41.7 \%$ & $46.8 \%$ & $45.6 \%$ \\
\hline & & Between 3.0 and 4.0 & Count & 7 & 35 & 42 \\
\hline & & & $\%$ within Refleclmpuls & $29.2 \%$ & $44.3 \%$ & $40.8 \%$ \\
\hline & & Total & Count & 24 & 79 & 103 \\
\hline & & & $\%$ within Refleclmpuls & $100.0 \%$ & $100.0 \%$ & $100.0 \%$ \\
\hline
\end{tabular}

\section{Chi-Square Tests}

\begin{tabular}{|ll|l|l|l|}
\hline HighSchoolType & & Value & df & $\begin{array}{l}\text { Asymp. Sig. } \\
\text { (2-sided) }\end{array}$ \\
\hline Private School & Pearson Chi-Square & 6.726 & 2 & .035 \\
& Likelihood Ratio & 5.925 & 2 & .052 \\
& N of Valid Cases & 103 & & \\
\hline
\end{tabular}

Table 13: Cross-tabulation: Mother's Education * High School Type.

\begin{tabular}{|c|c|c|c|c|c|}
\hline & & & \multicolumn{3}{|c|}{ HighSchoolType } \\
\hline & & & $\begin{array}{l}\text { Government } \\
\text { School }\end{array}$ & Private School & Total \\
\hline \multirow[t]{10}{*}{ MotherEducn } & \multirow[t]{2}{*}{ College/University } & Count & 86 & 128 & 214 \\
\hline & & $\begin{array}{l}\% \text { within } \\
\text { MotherEducn }\end{array}$ & $40.2 \%$ & $59.8 \%$ & $100.0 \%$ \\
\hline & \multirow[t]{2}{*}{ High School } & Count & 106 & 93 & 199 \\
\hline & & $\begin{array}{l}\% \text { within } \\
\text { MotherEducn }\end{array}$ & $53.3 \%$ & $46.7 \%$ & $100.0 \%$ \\
\hline & \multirow[t]{2}{*}{ Primary School } & Count & 198 & 44 & 242 \\
\hline & & $\begin{array}{l}\text { \% within } \\
\text { MotherEducn }\end{array}$ & $81.8 \%$ & $18.2 \%$ & $100.0 \%$ \\
\hline & \multirow[t]{2}{*}{ None } & Count & 47 & 6 & 53 \\
\hline & & $\begin{array}{l}\% \text { within } \\
\text { MotherEducn }\end{array}$ & $88.7 \%$ & $11.3 \%$ & $100.0 \%$ \\
\hline & \multirow[t]{2}{*}{ Total } & Count & 437 & 271 & 708 \\
\hline & & $\begin{array}{l}\text { \% within } \\
\text { MotherEducn }\end{array}$ & $61.7 \%$ & $38.3 \%$ & $100.0 \%$ \\
\hline
\end{tabular}




\section{Chi-Square Tests}

\begin{tabular}{|l|l|l|l|}
\hline & Value & $\mathrm{df}$ & $\begin{array}{l}\text { Asymp. Sig. (2- } \\
\text { sided) }\end{array}$ \\
\hline Pearson Chi-Square & $1.057 \mathrm{E} 2$ & 3 & .000 \\
Likelihood Ratio & 111.898 & 3 & .000 \\
N of Valid Cases & 708 & & \\
\hline
\end{tabular}

